\title{
KESESUAIAN ANTARA RENCANA PELAKSANAAN \\ PEMBELAJARAN DENGAN PELAKSANAAN PEMBELAJARAN PADA GURU MATEMATIKA KURIKULUM 2013
}

\author{
FITRIANI NUR, FITRIA, NUR KHALISAH LATUCONSINA, LISNASARI ANDI MATTOLIANG, \\ AHMAD FARHAM MAID \\ UIN Alauddin Makassar \\ Email: fitriani.nur@uin-alauddin.ac.id, fitria@gmail.com, nur.khalisah@uin- \\ alauddin.ac.id, lisnasari.mattoliang@uin-alauddin.ac.id, ahmad.farham@uin- \\ alauddin.ac.id
}

\begin{abstract}
:
The study aims to find out the suitability of the mathematics teachers' lesson plan with the 2013 curriculum, the mathematics teachers' learning implementation with the 2013 curriculum, and the lesson plan with the mathematics teacher's learning activities with the 2013 curriculum. The study used descriptive research with qualitative approach. The research subjects were 3 mathematics teachers of class X in the State Senior High School (SMAN) 11 Makassar. The documentation, observation sheet, and interview guidelines were the instruments used in this study. The analysis results of the lesson plan with the learning activities based on the 2013 curriculum in accordance with the cultural and education ministry regulation number 22 of the year 2016 about the Elementary and Secondary Education Standard Processes showed that the suitability of those three mathematics teachers' lesson plans with the learning implementation of the 2013 curriculum was categorized as very high with the percentage of $94.44 \%$, the suitability of the learning implementation in SMAN 11 Makassar at class X with the learning implementation of the 2013 curriculum was categorized as high with the percentage of $81.68 \%$, and the suitability of the lesson plan with the learning implementation based on the 2013 curriculum in SMAN 11 Makassar at class $X$ was categorized as low with the percentage of $62.17 \%$. The study finding also indicated that there was unsuitability between the lesson plan and the mathematics teachers' learning implementation of the 2013 curriculum at class X of SMAN 11 Makassar.
\end{abstract}

Keywords: Lesson Plan; The 2013 Curriculum

\section{PENDAHULUAN}

alah satu upaya memperbarui perubahan kurikulum KTSP 2006 ke kurikulum 2013 yaitu dengan dilakukan evaluasi kurikulum sesuai kebutuhan anak bangsa atau generasi muda. Perubahan tersebut juga berdasarkan pemikiran akan tantangan masa depan yaitu tantangan pada abad ke-21 yang ditandai dengan abad ilmu pengetahuan, knowledge-based society dan kompetensi masa depan. Hal ini sejalan dengan pendapat Waseso (2017), adanya Kurikulum 2013 yang dilatarbelakangi oleh kondisi perekonomian yang menuntut tenaga kerja berkualitas dan berdaya saing tinggi. Sedangkan menurut Karli (2014), perbedaan KTSP 2006 dan Kurikulum 2013 yaitu pada proses penyusunan RPP, silabus, format rapor, 
pendekatan/model pembelajaran, jam belajar dan komponen mata pelajaran. Penilaian proses dan model pembelajaran yang disarankan pada dasarnya sama. Kurikulum 2013 merupakan suatu hasil konstruksi kurikulum yang mengintegrasikan dua karakter besar yaitu kompetensi dan karakter peserta didik. Dalam proses pembelajaran yang menggunakan kurikulum 2013 peserta didik lebih aktif dan bersemangat dalam belajar. Kecenderungan Kurikulum 2013 yang mengarahkan peserta didik belajar secara kelompok mengakibatkan keterlibatan peserta didik cukup meningkat dalam proses pembelajaran.

Upaya penyederhanaan dan sifatnya yang tematik-integratif merupakan inti dari kurikulum 2013. Pemberian materi terintegrasi bertujuan agar peserta didik memiliki pengetahuan tentang penerapan pengetahuan dalam lingkungan sosial dan kehidupan sehari-hari serta menjadi pribadi yang tangguh dalam mengembangkan kreativitas peserta didik. Hal terberat dari kurikulum 2013 adalah bertujuan agar peserta didik memiliki kemampuan yang lebih baik dalam melakukan observasi, bertanya (wawancara), bernalar, dan mengomunikasikan (mempresentasikan) apa yang diketahui setelah menerima materi pembelajaran. Untuk meningkatkan kualitas dan kuantitas kegiatan pembelajaran maka yang dilakukan oleh guru yaitu, harus memiliki dan menguasai perencanaan pembelajaran, melaksanakan kegiatan yang direncanakan dan melakukan penilaian terhadap hasil dari proses pembelajaran.

Rencana Pelaksanaan Pembelajaran (RPP) merupakan rencana kegiatan pembelajaran tatap muka di kelas untuk satu pertemuan atau lebih (Permendikbud 65 tahun 2013). RPP juga didefinisikan sebagai perencanaan untuk memperkirakan tindakan apa yang akan dilakukan dalam kegiatan pembelajaran dengan mengkoordinasikan komponen pembelajaran yakni identitas pembelajaran, Standar Kompetensi (SK), Kompetensi Dasar (KD), indikator capaian, alokasi waktu, tujuan pembelajaran yang akan dicapai, materi pembelajaran, langkah-langkah pembelajaran, metode/model pembelajaran, alat dan sumber belajar, dan penilaian hasil pembelajaran (Hastuti, 2019). Menurut Ibrahim (2014), RPP adalah suatu sistem yang didalamnya terdiri dari Standar Kompetensi (SK) dan Kompetensi Dasar (KD) serta aturan kegiatan pembelajaran. Maka RPP dapat diartikan sebagai rencana kegiatan proses pembelajaran yang memuat komponen pembelajaran.

Guru mata pelajaran pada setiap satuan pendidikan diwajibkan menyusun RPP, sebagaimana ditegaskan dalam pemerintah melalui Permendikbud No. 65 Tahun 2013. Meskipun demikian, pada kenyataannya masih banyak guru yang belum mampu menyusun RPP kurikulum 2013. Salah satu factor penyebabnya karena tidak memahami hakikat dari RPP, prinsip penyusunan RPP, serta beranggapan bahwa menyusun/merancang RPP itu tidak penting. Faktor lainnya adalah guru memiliki jumlah jam mengajar yang banyak, sehingga RPP seringkali tidak tersedia sebelum proses pembelajaran, selain itu, guru beranggapan menulis 
RPP karena tuntutan administrasi sekolah, dan RPP tidak selalu dapat diterapkan di kelas. Akibatnya banyak guru yang menempuh jalan yang praktis seperti meminta file RPP milik teman dan mendownload dari google/internet. Sehingga ketika guru melaksanakan proses pembelajaran di kelas terjadilah ketidaksesuaian antara RPP yang digunakan dengan pelaksanaan pembelajarannya.

Sejalan dengan hal tersebut, hasil penelitian sebelumnya yang dilakukan oleh Aeni, Chandra dan Muspiroh (2016) menyebutkan yakni kesulitan guru antara lain: 1) kesulitan pada tahap proses perencanaan yaitu pada guru biologi, kesulitan yang terdapat pada saat penyusunan RPP yaitu apek perangkat awal, alokasi waktu, metode/model pembelajaran, sumber belajar, dan format penilaian (rubrik), 2) Kesulitan pada tahap proses pembelajaran, pada bagian aspek kegiatan pendahuluan, guru masih sulit membuat peserta didik untuk berkonsentrasi pada saat proses pembelajaran, guru masih sulit untuk menyampaikan tujuan pembelajaran yang akan dicapai. Bagian aspek kegiatan inti diantaranya guru masih sulit untuk menerapkan pendekatan saintifik (5M), guru masih kesulitan menggunakan metode/model pembelajaran, guru juga kurang aktif dalam proses pembelajaran. Pada bagian aspek kegiatan penutup, guru masih sulit membimbing peserta didik untuk menyimpulkan pembelajaran yang telah dilakukan, guru jarang memberikan umpan balik/feedback terhadap proses pembelajaran dan hasil pembelajaran, guru masih sulit untuk menilai proses pembelajaran yang telah dilakukan. Selain itu, hasil penelitian Clorawati, Rohiat dan Amir (2017) juga menunjukkan bahwa penerapan kurikulum 2013, persentase rata-rata guru yang telah menerapkan kurikulum 2013 adalah sebesar 66,67\% dengan kategori sebagian besar terlaksana. Secara khusus, perencanaan pembelajaran diperoleh $65,385 \%$, pelaksanaan pembelajaran diperoleh $57,692 \%$, dan penilaian hasil belajar diperoleh 76,923\% dengan kategori sebagian besar terlaksana. Adapun hasil penelitian Aryani (2014) menyimpulkan bahwa guru memiliki beberapa hambatan dalam kegiatan pelaksanaan penerapan pendekatan saintifik. Salah satu hambatan yang masih dialami guru yaitu hambatan dalam kegiatan awal pebelajaran, kegiatan inti pembelajaran dan kegiatan akhir pembelajaran. Guru masih perlu dilatih agar memiliki kompetensi yang baik dalam menyusun RPP.

Berdasarkan uraian di atas, maka dilakukan penelitian terkait Kesesuaian antara Rencana Pelaksanaan Pembelajaran dengan Pelaksanaan Pembelajaran pada Guru Matematika Kurikulum 2013. Hal ini dilakukan untuk memberikan informasi tentang RPP yang sesuai dengan standar Kurikulum 2013. Selain itu, diharapkan guru bisa semakin percaya diri dalam mendesain/merancang pembelajaran matematika yang lebih inovatif dan variatif.

\section{METODE PENELITIAN}

Pendekatan penelitian yang digunakan merupakan penelitian kualitatif. Menurut Bodgan dan Taylor menjelaskan bahwa penelitian kualitatif merupakan 
salah satu prosedur penelitian yang menghasilkan data deskriptif yang menggambarkan berupa ucapan atau tulisan dan tindakan orang-orang yang diamati. Pendekatan penelitian ini, digunakan untuk meneliti pada kondisi obyek yang alamiah, peneliti sebagai instrumen utama dalam penelitian ini, teknik pengumpulan data dilakukan secara triangulasi (gabungan), analisis data bersifat induktif, dan hasil penelitian kualitatif ini lebih menekankan makna daripada generalisasi. Subjek penelitian kualitatif dapat dilakukan hanya dengan satu subjek penelitian saja. Meski demikian, latar belakang atau individu yang hendaknya diteliti memiliki keunikan tersendiri. Keunikan itulah yang menentukan tingkat bobot/nilai ilmiah. Adapun subjek dalam penelitian ini yaitu guru matematika kelas X SMA Negeri 11 Makassar yang berjumlah 3 orang. Instrumen dan teknik pengumpulan data yang dilakukan dalam penelitian ini yaitu dengan menggunakan dokumentasi, lembar observasi, dan teknik wawancara. Teknik wawancara yang digunakan adalah wawancara semi terstruktur dan wawancara tidak terstruktur. Pada wawancara semi terstruktur, interviewer menanyakan serentetan pertanyaan yang sudah terstruktur, kemudian satu per satu diperdalam dalam mengorek keterangan lebih lanjut (Arikunto, 2006). Sedangkan pada wawancara tidak terstuktur tidak menggunakan pedoman wawancara yang sistematis dan lengkap untuk pengumpulan datanya.

Proses awal untuk analisis data dokumentasi RPP dilakukan dengan menganalisis instrumen lembar observasi tentang komponen RPP dan isi RPP berdasarkan kurikulum 2013. Berdasarkan skor yang diperoleh dari tiap komponen RPP dan isi RPP maka dapat dipersentasekan dan dideskripsikan secara rinci, dan jelas tingkat kelengkapan RPP dengan rancangan Kurikulum 2013. Persentase kelengkapan setiap RPP dengan Kurikulum 2013 dapat dihitung dengan menggunakan rumus (kemendikbud, 2013):

$$
\text { Nilai }=\frac{\text { Jumlah kriteria }}{\text { Banyak komponen yang diamati }} \times 100 \%
$$

Tabel 1. Kategori Kesesuaian Komponen dan Isi RPP Kurikulum 2013

\begin{tabular}{l|c}
\hline \multicolumn{1}{c|}{ Kategori } & Nilai \\
\hline Amat Sesuai (AS) & $90<\mathrm{AB} \leq 100$ \\
Sesuai (B) & $80<\mathrm{AB} \leq 89$ \\
Cukup (C) & $70<\mathrm{AB} \leq 79$ \\
Kurang (K) & $\leq 70$ \\
\hline
\end{tabular}

Sumber: Kemendikbud, 2013

Pelaksanaan pembelajaran dianalisis menggunakan instrumen lembar observasi tentang pelaksanaan proses pembelajaran. Persentase pelaksanaan proses pembelajaran yang didapat kemudian dideskripsikan secara rinci dan jelas, tingkat kesesuain proses pembelajaran dengan rancangan Kurikulum 2013. Persentase kesesuaian setiap pelaksanaan proses pembelajaran dapat dihitung dengan menggunakan rumus (Kemendikbud, 2013): 


$$
\text { Nilai }=\frac{\text { Jumlah kegiatan yang terlaksana }(\mathrm{YA})}{\text { Banyak komponen yang diamati }} \times 100 \%
$$

Tabel 2. Kategori Kesesuaian Pelaksanaan Kurikulum 2013

\begin{tabular}{l|l}
\hline \multicolumn{1}{c|}{ Kategori } & \multicolumn{1}{c}{ Nilai } \\
\hline Sangat Sesuai (AS) & $90<\mathrm{AB} \leq 100$ \\
Sesuai (B) & $80<\mathrm{AB} \leq 89$ \\
Cukup (C) & $70<\mathrm{AB} \leq 79$ \\
Kurang (K) & $60<\mathrm{AB} \leq 69$ \\
Tidak (T) & $\leq 60$
\end{tabular}

Sumber: Kemendikbud 2013

Hasil dari persentase di atas kemudian dirata-ratakan dengan menjumlahkan semua total persentase dan membagi dengan banyaknya komponen RPP, kemudian dikali dengan $100 \%$. Selanjutnya, data yang telah dianalisis diolah kembali dengan menggunakan model interaktif yang terdiri dari 3 tahapan yaitu reduksi data, penyajian data, verifikasi data dan penarikan kesimpulan.

\section{HASIL PENELITIAN DAN PEMBAHASAN}

Pengambilan data dilakukan dengan cara mendokumentasikan RPP guru matematika kemudian menganalisis, melakukan observasi pada saat pelaksanaan pembelajaran yang dilakukan oleh guru, dan melakukan wawancara kepada guru matematika kelas X di SMA Negeri 11 Makassar.

\section{Kesesuaian RPP dengan Kurikulum 2013}

Proses awal analisis data dokumentasi RPP dilakukan dengan menganalisis instrumen lembar observasi tentang komponen dan isi RPP berdasarkan kurikulum 2013. Analisis kelengkapan komponen dan isi RPP didasarkan pada ada atau tidaknya komponen sub variabidentitas mata pelajaran (meliputi satuan pendidikan, kelas, semester, mata pelajaran, metode pembelajaran, materi pokok, alokasi waktu), kompetensi inti, kompetensi dasar, indikator, tujuan pembelajaran, materi pembelajaran, metode pembelajaran, media pembelajaran, alat dan bahan, sumber belajar, kegiatan pendahuluan, inti, penutup, dan penilaian. Persentase kesesuaian RPP yang dibuat oleh guru mata pelajaran matematika kelas X SMA Negeri 11 Makassar dengan kurikulum 2013 dapat dilihat pada tabel berikut:

Tabel 3. Persentase Kesesuaian antara RPP dengan Kurikulum 2013

\begin{tabular}{clcc}
\hline No. & Nama guru/Subjek & Persentase & Kategori \\
\hline 1 & Dra. Hj. Habriah Ahmad, M.Pd & $94,44 \%$ & Sangat Sesuai \\
2 & Dra. Kalsum & $94,44 \%$ & Sangat Sesuai \\
3 & Sultan Majid, S.Pd & $94,44 \%$ & Sangat Sesuai \\
\hline \multicolumn{2}{c}{ Rata-rata persentase } & $94,44 \%$ & Sangat Sesuai \\
\hline
\end{tabular}

Berdasarkan Tabel 3 menunjukkan bahwa kelengkapan komponen RPP dan isi RPP yang dibuat oleh guru/subjek 1, 2, dan 3 memiliki rata-rata persentase sebesar 94,44\% dimana, rata-rata tersebut termasuk kedalam kategori sangat sesuai. Persentase yang diperoleh Guru 1, 2 dan 3 memiliki persentase yang sama yaitu 
94,44\% itu dikarenakan keduanya memiliki RPP yang sama juga karena mereka mengerjakannya secara kelompok atau saling berdiskusi.

\section{Kesesuaian Pelaksanaan Pembelajaran dengan Kurikulum 2013}

Pemerolehan data dilakukan dengan melakukan pengamatan pada tiga guru matematika kelas X SMA Negeri 11 Makassar, dimana proses pembelajaran kurikulum 2013 yang terdiri dari tiga langkah-langkah kegiatan yaitu kegiatan pendahuluan, kegiatan inti, dan kegiatan penutup.

Keterlaksanaan proses pembelajaran menggunakan kurikulum 2013 disajikan pada Tabel 4 berikut:

Tabel 4. Kesesuaian Pelaksanaan Pembelajaran Menggunakan Kurikulum 2013

\begin{tabular}{clcc}
\hline No. & \multicolumn{1}{c}{ Nama guru/Subjek } & Persentase & Kategori \\
\hline 1 & Dra. Hj. Habriah Ahmad, M.Pd & $86,20 \%$ & Sesuai \\
2 & Dra. Kalsum & $68,96 \%$ & Kurang Sesuai \\
3 & Sultan Majid, S.Pd & $89,65 \%$ & Sesuai \\
\hline & Rata-rata persentase & $\mathbf{8 1 , 6 8 \%}$ & Sesuai \\
\hline
\end{tabular}

pembelajaran yang dilakukan oleh guru 1, 2, dan 3, yang memiliki persentase yang paling tinggi yaitu guru 3 yaitu sebesar $89,65 \%$, itu dikarenakan pada saat proses pembelajaran guru 3 sangat memahami tentang pelaksanaan/penerapan kurikulum 2013. Kemudian yang memiliki persentase tertinggi kedua yaitu guru 1 sebesar $86,20 \%$ dengan kategori sesuai dengan pelaksanaan kurikulum 2013, persesentase tertinggi ketiga yaitu guru 2 sebesar 68,96\% dengan kategori kurang sesuai dengan pelaksanaan/penerapan pembelajaran kurikulum 2013. Dari keseluruhan hasil persentase di atas diperoleh rata-ratanya sebesar 81,68 \% dengan kategori jika semua guru digabungkan yaitu sesuai dengan pelaksanaan/penerapan pembelajaran kurikulum 2013.

\section{Kesesuaian RPP dengan Pelaksanaan Pembelajaran Kurikulum 2013}

Analisis ini dilakukan dengan mengamati kesesuaian RPP yang dibuat oleh guru dengan pelaksanaan pembelajaran di kelas. Selanjutnya, kesesuaian antara RPP dan pelaksanaan pembelajaran kurikulum 2013 yang dibuat oleh guru matematika kelas X SMA Negeri 11 Makassar dapat dilihat persentasenya pada tabel 5.

Tabel 5. Persentase Kesesuaian antara RPP dengan Pelaksanaan Pembelajaran Kurikulum 2013

\begin{tabular}{clcc}
\hline No. & \multicolumn{1}{c}{ Nama guru/Subjek } & Persentase & Kategori \\
\hline 1 & Dra. Hj. Habriah Ahmad, M.Pd & $67,30 \%$ & Kurang Sesuai \\
2 & Dra. Kalsum & $57,69 \%$ & Tidak Sesuai \\
3 & Sultan Majid, S.Pd & $61,54 \%$ & Kurang Sesuai \\
\hline & Rata-rata Persentase & $62,17 \%$ & Kurang Sesuai \\
\hline
\end{tabular}


Berdasarkan Tabel 5 menunjukkan bahwa kesesuaian antara RPP dengan proses pembelajaran yang dilakukan oleh guru matematika memiliki kategori sesuai, cukup sesuai, dan tidak sesuai. Terdapat guru yang memiliki hasil persentase yang hampir sama yaitu pada guru 1 dan 3 yang masing-masing hasil persentasenya di atas $60 \%$ dengan kategori kedua guru tersebut yaitu kurang sesuai, dapat dikatakan bahwa pada saat proses pelaksanaan pembelajaran, pelaksaanaan pembelajaran yang mereka lakukan masih kurang sesuai dengan RPP yang mereka buat, namun ada yang juga yang memperoleh hasil persentase sebesar $57,67 \%$ yaitu guru 2 dengan kategori tidak sesuai antara RPP yang mereka buat dengan pelaksanaan pembelajaran berdasarkan kurikulum 2013. Dari hasil keseluruhan persentase di atas diperoleh nilai rata-ratanya sebesar $62,17 \%$ yang kategorinya jika semua guru digabungkan yaitu kurang sesuai antara RPP yang mereka buat dengan pelaksanaan pembelajaran berdasarkan kurikulum 2013.

Berdasarkan data hasil dokumentasi RPP meliputi komponen RPP kelengkapan RPP dan isi RPP menunjukkan bahwa guru matematika kelas X SMA Negeri 11 Makassar memiliki rata-rata persentase 94,44\% dengan kriteria sangat sesuai dengan kurikulum 2013. Komponen RPP yang paling banyak tidak terdapat pada komponen RPP dalam kegiatan pendahuluan yaitu pemberian acuan pada peserta didik. Namun pada penilaian isi RPP dan komponennya, semua memiliki skor yang sama yaitu $94,44 \%$ walaupun ada yang berbeda, tidak ada kesesuaian dari isi dan komponennya sehingga yang diperoleh bahwa komponen RPP dan isi RPP yang dibuat oleh guru kelas X SMA Negeri 11 Makassar tergolong sangat sesuai. Terdapat 2 RPP yang sama dalam pengamatan ini karena mereka saling berdiskusi/kerja kelompok dalam mengerjakannya.

Komponen kelengkapan RPP kurikulum 2013 Berdasarkan Permendikbud No. 22 tahun 2016 tentang Standar Proses Pendidikan Dasar Dan Menengah tentang penerapan kurikulum 2013 bahwa RPP paling sedikit Identitas mata pelajaran yaitu (satuan pendidikan, kelas/semester, mata pelajaran atau tema pelajaran, jumlah pertemuan), Kompotensi Dasar, Indikator pembelajaran, Tujuan pembelajaran, Materi ajar (fakta, konsep, prinsip dan prosedur yang relevan), Alokasi waktu, Metode/model pembelajaran, Kegiatan pembelajaran meliputi kegiatan pendahuluan, kegiatan inti (mengamati, menanya, mengumpulkan data, mengasosiasi, dan mengkomunikasikan), kegiatan penutup dan penilaian hasil pembelajaran. Jika dikaitkan dengan hasil wawancara oleh guru matematika/subjek tersebut tentang pembuatan RPP, semuanya mengatakan bahwa yang sulit sebenarnya yaitu dalam mengolah model dan materi pembelajaran yang semuanya harus dituliskan/dicantumkan, namun jika dilihat dari hasil pengamatan semua komponen sudah sesuai karena semua guru sudah terbiasa dalam membuat yang namanya RPP, hanya saja harus menyesuaikan antara model karakteristik peserta didik. 
Berdasarkan data hasil analsis lembar observasi menunjukkan bahwa proses pelaksanaan pembelajaran yang dilakukan oleh guru 1, 2, dan 3 memiliki rata-rata persentase sebesar $81,68 \%$ dengan kategori sesuai. Persentase yang tertinggi yaitu guru 3 sebesar $89,65 \%$, hal ini dikarenakan pada saat proses pembelajaran guru 3 sangat memahami tentang pelaksanaan kurikulum 2013. Hasil wawancara guru 3 juga mengatakan bahwa "pelaksanaan pembelajaran dia sebenarnya masih berat diterapkan dalam peserta didik siswi disini, karena kemampuan dasarnya anak peserta didik disini masih kurang. Namun saya berusaha untuk tetap menerapkan scientific approach karena saya sudah tuangkan dalam perangkat pembelajaran saya yaitu pada RPP saya, jika pun ini berhasil dalam menerapkannya pada saat proses pembelajaran itu dikarenakan interaksi pendidik dengan peserta didik saat itu interaksinya bisa terbilang baik". Menurut Sofan Amri pelaksanaan proses pembelajaran ada tiga tahap kegiatan yang meliputi kegiatan pendahuluan, kegiatan inti dan kegiatan penutup, dimana semuanya itu proses Pelaksanaan pembelajaran yang merupakan penerapan dari RPP. Dalam kegiatan pendahuluan, guru hendaknya: a) menyiapkan peserta didik secara psikis dan fisik untuk mengikuti proses pembelajaran yang akan dilaksanakan; b) mengajukan pertanyaanpertanyaan yang berkaitan dengan pengetahuan sebelumnya dan materi yang akan dipelajari; c) menjelaskan tujuan pembelajaran yang akan dicapai atau kompetensi dasar yang akan dicapai; d) menyampaikan materi yang akan dipelajari dan penjelasan uraian kegiatan sesuai silabus. Kegiatan inti merupakan proses pelaksanaan pembelajran untuk mencapai KD yang dilakukan secara interaktif, inspiratif, menyenangkan, menantang, serta memotivasi peserta didik untuk berpartisipasi aktif dalam proses pembelajaran. kegiatan inti menggunakan metode yang diseseuaikan dengan karakteristik yang dimiliki peserta didik dan mata pelajaran yang akan dipelajari, yang dapat meliputi proses eksplorasi, elaborasi, dan konfirmasi. Sedangkan pada kegiatan penutup guru : a) bersama dengan peserta didik, guru membimbing membuat rangkuman atau simpulan pelajaran; b) melakukan penilaian dan refleksi terhadap kegiatan yang sudah dilaksanakan; c) memberikan umpan balik/feedback terhadap proses dan hasil pembelajaran; d) merencanakan kegiatan tindak lanjut yang akan dilakukan untuk pertemuan selanjutnya dapat dilakukan dalam bentuk pembelajaran remedi, program pengayaan, layanan konseling atau memberikan tugas, baik tugas individu maupun kelompok sesuai dengan hasil belajar masing-masing peserta didik, $f$. Menyampaikan rencana pembelajaran dapat dilakukan dengan menyampaikan materi yang akan dipelajari pada pertemuan berikutnya.

Selanjutnya, persentase tertinggi kedua yaitu guru 1 sebesar $86,20 \%$ dengan kategori sesuai dengan pelaksanaan kurikulum 2013 jika dikaitkan dengan hasil wawancara guru 2 tersebut, dia mengatakan bahwa penerapan scientific approach dalam proses pembelajaran matematika, tidak ada masalah karena setiap mengajar 
dia sering menerapkannya bahkan saat kurikulum 2013 belum diterapkan, yang jelas sebagai seorang guru kita harus pandai-pandai mengolah kelas agar bisa langsung diterapkan dengan baik. Untuk persesentase yang terendah yaitu sebesar 68,96\% oleh guru 2 yang kategorinya kurang sesuai dengan pelaksanaan pembelajaran kurikulum 2013 jika dikaitkan dengan hasil wawancara guru 2, mengatakan bahwa "sangat sulit diterapkan, karena biasanya anak-anak disini susah dalam mendengarkan gurunya, walaupun kita sebagai gurunya sudah menegur biasanya beberapa menit kemudian akan dilakukan lagi, jadi dalam menerapkan pendekatan saintifik biasanya agak susah menerapkannya apalagi jam pelajaran sudah ada pada jam terakhir, itu sangat susah menerapkannya karena peserta didik biasanya sudah tidak terlalu fokus dalam memperhatikan gurunya apalagi dalam pelajaran matematika".

Berdasarkan data hasil analisis lembar observasi dan dokumentasi menunjukkan bahwa kesesuaian antara RPP dengan proses pembelajaran dengan RPP yang dilakukan oleh guru matematika memiliki kategori sesuai, cukup sesuai, dan tidak sesuai. Ada 2 guru yang memiliki hasil persentase yang nyaris sama yaitu guru 1 dan 3 dimana masing-masing hasil persentasenya di atas 60\% dengan kategori kedua guru tersebut yaitu kurang sesuai, dapat dikatakan bahwa pada pelaksanaan proses pelaksanaan pembelajaran sudah sangat sesuai dengan RPP yang mereka buat, dan jika dikaitkan dengan hasil wawancara dengan kedua guru tersebut mengatakan bahwa pada pembuatan RPP mereka tidak mengalami kesulitan dalam membuatnya baik itu dalam penilaian autentiknya. Sedangkan guru 1 mengatakan bahwa upaya yang dapat dilakukan seorang guru itu dalam menyesuaiakan RPP dengan kurikulum 2013 dapat dilakukan dengan browsing di internet, selalu mengikuti grup yang ada di Whatsapp dan Facebook tentang informasi seperti RPP dan lain-lainnya, mengikuti pelatihan, seperti mengikuti pelatihan di MGMP. Sama saja dengan guru 3, guru tersebut juga mengatakan hal demikian. Namun ada juga yang mendapat hasil persentase sebesar 57,69\% yaitu guru 2 dengan kategori tidak sesuai antara RPP dengan pelaksanaan pembelajaran, dikaitkan dengan hasil wawancara yang telah dilakukan, guru tersebut hanya membuat RPP secara berkelompok dengan guru lainnya tetapi dalam melaksanakan pelakasanaannya tergolong tidak sesuai karena guru tersebut mengupayakan untuk menyesuaikan RPP dengan pelaksanaannya saja tanpa melihat perencanaan yang dibuat sebelumnya. Serta yang menjadi kesulitan dalam menyusun/merancang RPP pada lampiran materi, karena semua diminta untuk dituliskan yang ada pada buku, penjelasan hingga langkah-langkahnya juga harus ditulis, jadi ketika mengajar hanya membawa RPP, tidak akan ada apa-apa karena materinya semua sudah dilampirkan, namun guru tersebut juga mengupayakan agar apa yang dituliskan di dalam RPP yang dibuatnya sesuai dengan pelaksanaan proses pembelajaran meskipun 
sewaktu-waktu ada komponen-komponen pembelajaran yang masih saja terlupakan untuk diterapkan/diaplikasikan di dalam kelas.

Dari data keseluruhan untuk hasil persentase dapat dilihat bahwa rata-ratanya sebesar $62,17 \%$ dengan kategori jika semua guru digabungkan yaitu kurang sesuai antara RPP dengan pelaksanaan proses pembelajaran kurikulum 2013. Menurut Ali Hamzah (2014), suatu kegiatan tidak akan berjalan dengan baik tanpa adanya sebuah rencana, terlebih jika berkaitan dengan pendidikan dimana aktivitasnya harus lebih efektif. Perencanaan memiliki kedudukan yang sangat penting di dalam proses pembelajaran. Seorang pendidik yang berdedikasi tinggi tidak hanya akan bertugas apa adanya saja, akan tetapi juga membuat rencana dengan matang dan melaksanakan sesuai dengan rencana itu. Artinya dalam melaksanakan proses pembelajaran seorang guru dituntut untuk berpegang pada RPP agar tidak 'ngawur' dalam melaksanakan pembelajarannya. Guru dengan jenis ini mempunyai kemantapan hati untuk mendidik kader bangsa yang lebih berkualitas. Ibrahim (2015), juga menambahkan bahwa penggunaan model/ metode/ pendekatan/ strategi pembelajaran yang kurang sesuai dengan apa yang telah diprogramkan pada RPP menyebabkan peseta didik kurang terlibat secara aktif dalam mengikuti pembelajaran. Sehingga berdasarkan hasil penelitian ini diharapkan dapat menjadi dasar bagi instansi terkait untuk melakukan pelatihan kurikulum 2013 secara merata, dan melakukan pendampingan kurikulum kurikulum 2013 dengan lebih intensif lagi. Diskusi setiap guru mata pelajaran sebelum membuat RPP dalam bentuk MGMP juga perlu ditingkatkan untuk menelaah kurikulum dan meningkatkan kualitas pembelajaran.

\section{PENUTUP/SIMPULAN}

Berdasarkan hasil penelitian dan pembahasan, maka diperoleh beberapa kesimpulan yaitu: 1) kesesuaian antara Rencana Pelaksanaan Pembelajaran dengan kurikulum 2013 di SMA Negeri 11 Makassar pada kelas X yang terdiri dari tiga guru matematika dikategorikan sangat sesuai antara Rencana Pelaksanaan Pembelajaran dengan pelaksanaan proses pembelajaran kurikulum 2013 sebesar $94,44 \%, 2)$ kesesuaian antara pelaksanaan pembelajaran berdasarkan kurikulum 2013 di SMA Negeri 11 Makassar pada kelas X yang terdiri dari tiga guru matematika berdada pada kategori sesuai dengan pelaksanaan pembelajaran kurikulum 2013 sebesar 81,68\%, 3) kesesuaian antara Rencana Pelaksanaan Pembelajaran dengan Pelaksanaan pembelajaran berdasarkan kurikulum 2013 di SMA Negeri 11 Makassar pada kelas $\mathrm{X}$ yang terdiri dari tiga guru matematika berada pada kategori kurang sesuai antara Rencana Pelaksanaan Pembelajaran dengan pelaksanaan pembelajaran kurikulum 2013 sebesar 62,17\%. Dengan demikian, perlu untuk dilakukan pengembangan instrumen penelitian yang lebih rinci/lebih baik dan mengikuti kurikulum 2013 yang berlaku. 


\section{DAFTAR PUSTAKA}

Aeni, U., Chandra, E., \& Muspiroh, N. (2016). Identifikasi Kesulitan Guru Biologi dalam Melaksanakan Pembelajaran Kurikulum 2013 di SMA Negeri 1 Susukan Cirebon. Scientiae Educatia: Jurnal Sains Dan Pendidikan Sains, 5.

Amri, S. (2013). Pengembangan dan model pembelajaran dalam kurikulum 2013. Jakarta: PT. Prestasi Pustakaraya.

Arikunto, Suharsimi. (2006). Prosedur Penelitian Suatu Pendekatan Praktik, (Cet.13, Edisi Revisi VI). Jakarta: PT RinekaCipta.

Aryani, M. (2014). Studi Kasus Penerapan Pendekatan Saintifik pada Guru-Guru Di SMAN 1 Bawang (Studi pada Tahun Ajaran 2013/2014). Economic Education Analysis Journal, 3(3). Retrieved from https://journal.unnes.ac.id/sju/index.php/eeaj/article/view/4511

Clorawati, A. R., Rohiat, S., \& Amir, H. (2017). Implementasi Kurikulum 2013 Bagi Guru Kimia Di SMA Negeri Sekota Bengkulu. Jurnal Pendidikan Dan IImu Kimia, 1(2), 132-135.

Hamzah, Ali. (2014). Perencanaan dan strategi pembelajaran matematika. Jakarta: PT. Raja Grafindo Persada.

Hastuti, D. (2019). Upaya meningkatkan Kompetensi Guru Menyusun Rencana Pelaksanaan Pembelajaran Tematik melalui Penerapan Supervisi Klinis Terhadap Guru Kelas I, II, IV dan VI SDN Kayupak 02 Kecamatan Polokarto Semester I Tahu Pelajaran 2018/2019. 10.

Ibrahim, M. M. (2014). Implementasi Kurikulum 2013 Rekontruksi Kompetensi, Revolusi Pembelajaran dan Refomasi Penilaian. Makassar: Alauddin University Press.

Ibrahim. (2015). Deskripsi Implementasi Kurikulum 2013 dalam Proses Pembelajaran Matematika di SMA Negeri 3 Maros Kabupaten Maros. Jurnal Daya Matematis, 3 (3), 370-378.

Karli, H. (2014). Perbedaan Kurikulum Tingkat Satuan Pendidikan 2006 dan Kurikulum 2013 untuk Jenjang Sekolah Dasar. Jurnal Pendidikan Penabur.

Kementerian Pendidikan dan Kebudayaan. (2013). Bahan Ajar Training of Trainer (TOT) Implementasi Kurikulum 2013 Penyusunan Rencana Pelaksanaan Pembelajaran (RPP) SD/SMP/SMA/SMK. Retrieved June 4, 2016, from www.informasiterbaru.web.id.pdf

Waseso, H. P. (2017). Studi Kritis Terhadap Kurikulum MI/SD 2013. Jurnal Pendidikan Dan Pembelajaran Dasar, 4(1), 191. 